\title{
Properties of Ribonucleic Acid and Coat Protein of Peanut Chlorotic Ring Mottle Virus
}

\author{
Fumiyoshi Fukumoto*, Mitsuro IwaKI** and Tsuneo TsuChIZAKI*
}

Key words : peanut chlorotic ring mottle virus, potyvirus, RNA glyoxalation, coat protein.

Peanut chlorotic ring mottle virus (PCRMV) which belongs to the potyvirus group occurs very widely on peanut in the South East Asian countries. PCRMV shows a very distant serological relationship with peanut mottle virus (PnMV), and also a positive reaction with blackeye cowpea mosaic virus (BlCMV), bean common mosaic virus (BCMV) and soybean mosaic virus $(\mathrm{SMV})^{1)}$. This paper describes some properties of the nucleic acid and coat protein of PCRMV, several potyviruses pathogenic to legumes as well as of turnip mosaic virus (TuMV).

PCRMV was purified as described in a previous report ${ }^{1)}$. Isolation of PCRMV-RNA was performed by the method of Brakke and Van Pelt ${ }^{2)}$ with a few modification. PCRMV-RNA was prepared by disrupting the virions in $10 \mathrm{mM}$ sodium phosphate buffer (Na-P.B.), pH 7.0, containing 1\% sodium dodecyl sulfate (SDS) and EDTA-treated bentonite, followed by sucrose density gradient centrifugation. The fractions which were associated with the infectivity on Chenopodium amaranticolor were concentrated by precipitation with ethanol. The pellet was resuspended in $10 \mathrm{mM} \mathrm{Na}-\mathrm{P}$. B., $\mathrm{pH} 7.0$, and stored at $-70 \mathrm{C}$ until use. RNA concentration was determined spectrophotometrically by using an extinction coefficient of $24 \mathrm{~cm}^{2} \mathrm{mg}^{-1}$ at $260 \mathrm{~nm}$.

Nuclease treatment was carried out by mixing the solution with $1 \mu \mathrm{g} / \mathrm{ml}$ of pancreatic ribonuclease (RNase) (Sigma) or $5 \mu \mathrm{g} / \mathrm{ml}$ deoxyribonuclease (DNase) (P-L Biochemical Inc.) in the presence of $5 \mathrm{mM} \mathrm{MgCl}$ and incubating at $35 \mathrm{C}$ for $30 \mathrm{~min}$. The preparation was then centrifuged on a linear sucrose density gradient column for $3 \mathrm{hr}$ at 216 , $400 \times \mathrm{g}$ in a Hitachi RPS65T rotor at $4 \mathrm{C}$. The gradients were scanned at $254 \mathrm{~nm}$ by an absorbance monitor (ISCO model UA-5) equipped with a density gradient fractionator (ISCO model 640). Reaction of nucleic acid with formaldehyde was analysed by the method of Miura et al. ${ }^{3}$.

Molecular weight (MW) of viral RNA was determined by analysing the sedimentation of RNA using linear sucrose density gradient centrifugation, and the electrophoretic mobility relative to the standard markers by agarose submarine gel electrophoresis.

\footnotetext{
* National Agriculture Research Center, Tsukuba Science City, Yatabe, Ibaraki 305, Japan 農林 水産省農研センター

** National Institute of Agro-Environmental Sciences, Tsukuba Science City, Yatabe Ibaraki 305, Japan 農林水産省農業環境技術研究所

1) Fukumoto, F., Thongmeearkom, P., Iwaki, M., Choopanya, D., Tsuchizaki, T., Iizuka, I., Sarindu, N., Deema, N., Ong, C. A., and Saleh, N. (1986). JARQ In press. 2) Brakke, M. K. and Van Pelt. N. (1970). Virology $42: 699-706$. 3) Miura, M., Kimura, I. and Suzuki, N. (1966). Ibid. $28: 571-579$.
} 
To determine the sedimentation coefficient of RNA, 23S (MW: $1.009 \times 10^{6}$ ) and $16 \mathrm{~S}$ $\left(\mathrm{MW}: 0.534 \times 10^{6}\right)$ ribosomal RNAs of Escherichia coli ${ }^{4,5)}$ were used as markers. The preparations of RNA and SDS-ciisrupted virus were centrifuged as described previously. To calculate the MW of RNA from the $S$ values, the formula $M=1557 S^{2.07}$ was used ${ }^{6}$.

Agarose submarine gel electrophoresis was carried out as follows: the preparations of non-denatured RNA and SDS-disrupted virus electrophoresed at $80 \mathrm{~V}$ for $3 \mathrm{hr}$ in $1 \%$ agarose gel $(13.5 \times 13.5 \mathrm{~cm}, 4 \mathrm{~mm}$ thick $)$ in $10 \mathrm{mM} \mathrm{Na}$-P. B., pH 7.0. The gel was stained with ethidium bromide $(1 \mu \mathrm{g} / \mathrm{ml})$, placed on an illuminator (260 nm wavelength), and photographed. The denatured RNAs were prepared in $1 \mathrm{M}$ glyoxal, 50\% (v/v) dimethyl sulfoxide, $10 \mathrm{mM}$ Na-P. B., pH 7.0, as described by MacMaster and Carmichael ${ }^{n}$. These preparations were electrophoresed at $80 \mathrm{~V}$ for $4 \mathrm{hr}$ in $0.75 \%$ agarose gel. The gel was stained with $0.05 \%$ Toluidine Blue 0 and destained with $60 \mathrm{mM} \mathrm{Na-P.B.,pH} \mathrm{7.0,} \mathrm{as} \mathrm{des-}$ cribed by Murant et al..$^{8)}$.

The following RNA species were used as standards for the estimation of RNA MW: TMV-RNA, MW $2.19 \times 10^{6}$ 9) ; tobacco ringspot virus (TobRSV) RNA 1 and RNA 2, MW $2.4 \times 10^{6}, 1.4 \times 10^{6}$ (non-denaturing condition), or $2.73 \times 10^{6}, 1.34 \times 10^{6}$ (glyoxalated denaturing condition) ${ }^{8)} ; 23 \mathrm{~S}$ and $16 \mathrm{~S}$ ribosomal RNA as described above.

Polyacrylamide gel electrophoresis (PAGE) of viral proteins was performed according to the method of Laemmli ${ }^{16)}$ using a $10 \%$ acrylamide slab gel. MW markers included bovine serum albumin (MW 68,000), ovalbumin $(45,000)$, chymotrypsinogen A $(25,000)$ (Boehlinger Mannheim), TobRSV protein subunits $(54,000)$ and southern bean mosaic virus protein subunits $(29,000)$.

PCRMV-RNA showed a maximum UV absorption at $258 \mathrm{~nm}$ and minimum at $238 \mathrm{~nm}$. The ratios of $\mathrm{OD}_{258} / \mathrm{OD}_{238}$ and $\mathrm{OD}_{258} / \mathrm{OD}_{28}$, were 1.86 and 2.10 , respectively. Native PCRMV-RNA was sedimented as a single band by sucrose density gradient centrifugation, and the RNA. ( $5 \mu \mathrm{g} / \mathrm{ml}$ ) caused local lesions (average number 74 per one leaf) on the inoculated leaves of $C$. amaranticolor. On the other hand, when PCRMV-RNA $(500 \mu \mathrm{g} / \mathrm{ml})$ had been treated with RNase, the sedimenting component disappeared, and its infectivity was lost completely. Similar treatment with DNase in the presence of $5 \mathrm{mM} \mathrm{MgCl}$ had no effect on the sedimentation pattern and infectivity. After $24 \mathrm{hr}$ incubation with formaldehyde, PCRMV-RNA exhibited a hyperchromicity of $29 \%$ and shift of 2-4 nm of longer wavelength in the ultraviolet absorption spectrum. These results indicate that the nucleic acid of PCRMV is a single-stranded RNA.

PCRMV-RNA was centrifuged with marker RNAs to estimate the sedimentation coefficient, and the MW of viral RNA was calculated. In twelve repetitions of the experiments, PCRMV-RNA showed an average sedimentation coefficient of $39.6 \pm 1.5$, and MW of viral RNA was calculated as $3.16 \times 10^{6}$ daltons. By the same procedure, MWs of RNA of the other potyviruses were calculated as shown in Table 1.

4) Brosius, J., Palmer, M. L., Kennedy, P. J. and Noller, H. F. (1978). Proc. Natl. Acad. Sci. USA $75: 4801-4805$. 5) Brosius, J., Dull, T. J. and Noller, H. F. (1980). Ibid. $77: 201-204$. 6) Hull, R., Rees, M. W. and Short, M. N. (1969). Virology $37: 404-415$. 7) MacMaster, G. K. and Carmichael, G. G. (1977). Proc. Natl. Acad. Sci. USA 74: 4835-4838. 8) Murant, A. F., Margaret Taylor, Duncan, G. H. and Raschké, J. H. (1981). J. gen. Virol. $53: 321-332$. 9) Casper, D. L. D. (1963). Chemistry $18: 37-121$. 10) Laemmli, U. K. (1970). Nature $227: 680-685$. 
When non-denatured PCRMV-RNA was electrophoresed in 196 agarose gel, a rectiilnear relationship was observed only among the mobilities of the RNA standards of TMV-RNA and TobRSV-RNAs, while ribosomal RNAs were out of the line (Fig. 1). Based

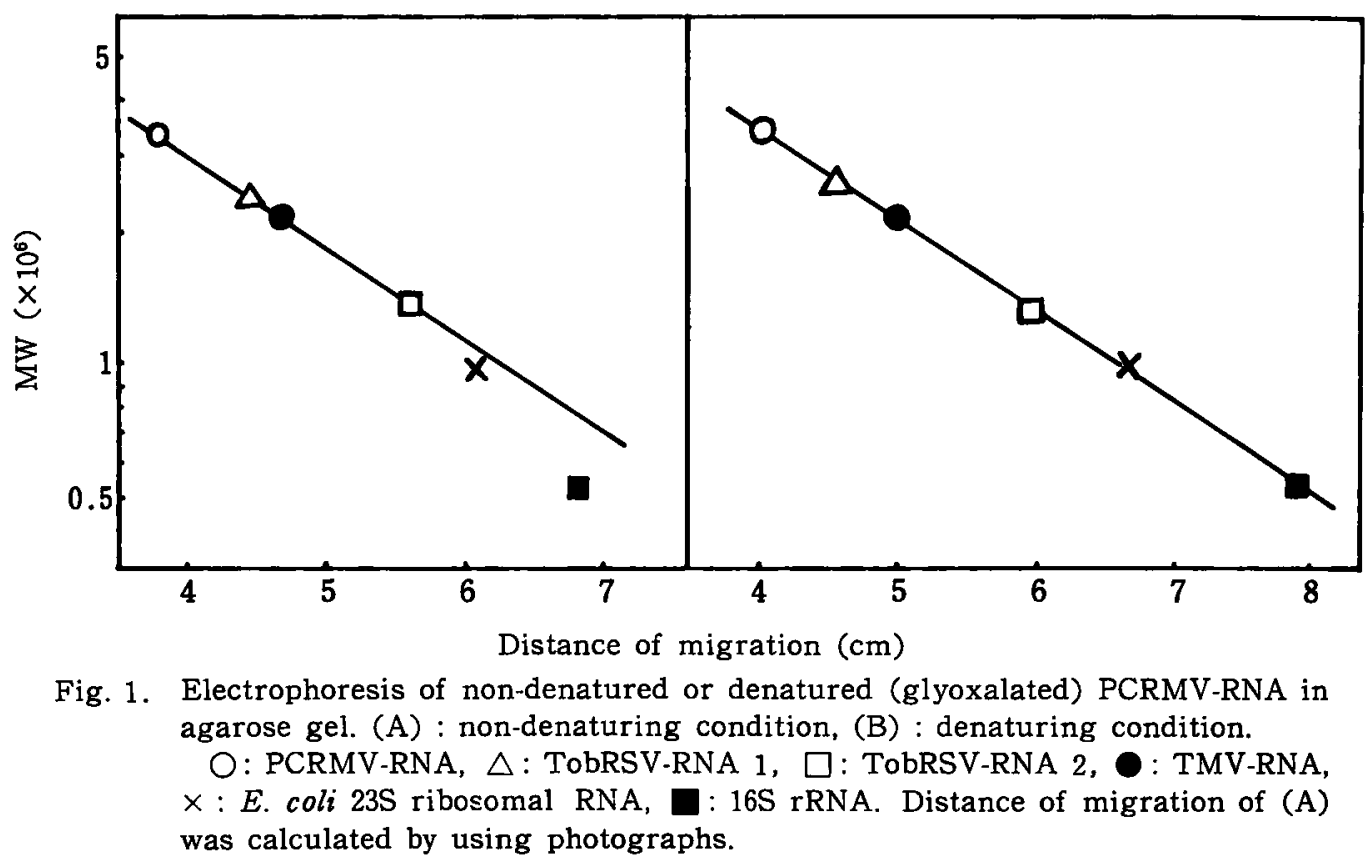

on the former RNA standards, MW of non-denatured PCRMV-RNA was calculated as $3.32 \pm 0.12 \times 10^{6}$ daltons. MW of RNA in SDS-disrupted PCRMV showed a similar value $\left(3.35 \pm 0.07 \times 10^{6}\right)$. On the other hand, when glyoxalated PCRMV-RNA was electrophoresed in $0.75 \%$ agarose gel, a rectilinear relationship was observed among the mobilities of all the RNA standards (Fig. 1) and the MW of PCRMV-RNA was thus estimated at $3.49 \pm 0.08 \times 10^{6}$ daltons. The glyoxalated preparation of the SDS-disrupted virions also gave the same estimate of $3.49 \pm 0.04 \times 10^{6}$ daltons for $\mathrm{MW}$. The values of the MWs of RNAs from SDS-disrupted virions for the other potyviruses are listed in Table 1.

The values of MWs of RNAs for the potyviruses estimated by sedimentation analysis and agarose gel electrophoresis were different, and the estimates of RNAs by agarose gel electrophoresis under denaturing conditions were slightly larger than those of RNAs under non-denaturing conditions. Murant et al. ${ }^{8)}$ reported that the electrophoresis of glyoxalated RNA in agarose gels was a reliable method for the determination of MW up to at least about $3.5 \times 10^{6}$ by using 13 plant viruses. This is the first report on the comparison of $\mathrm{MW}$ of glyoxalated RNAs of viruses belonging to the potyvirus group.

SDS-PAGE analysis of the coat protein of a freshly purified PCRMV revealed the presence of a main component with a $\mathrm{MW}$ of 35,600 and two smaller ones with $\mathrm{MWs}$ of 33,400 and 27,800 . One to three components were observed in SDS-PAGE for the other potyviruses, and MWs of the main coat protein of PnMV-PN, PnMV-T and TuMV were $30,900,31,600$ and 33,000 , respectively. These values are the means of $10-23 \mathrm{de}-$ 
Table 1. Molecular weights of viral ribonucleic acid of some potyviruses determined by agarose gel electrophoresis and sucrose density gradient centrifugation under non-denaturing and denaturing conditions

\begin{tabular}{l|c|c|c|c}
\hline \multirow{2}{*}{ Virus } & \multicolumn{2}{|c|}{ Agarose gel electrophoresis } & \multicolumn{2}{|c}{$\begin{array}{l}\text { Sucrose density gradient } \\
\text { centrifugation }\end{array}$} \\
\cline { 2 - 3 } \cline { 5 - 5 } & $\begin{array}{l}\text { Non-denaturing } \\
\text { condition }\end{array}$ & $\begin{array}{l}\text { Denaturing } \\
\text { conditiona) }\end{array}$ & \multicolumn{2}{|c}{ Non-denaturing condition } \\
\cline { 2 - 3 } \cline { 5 - 5 } & $\mathrm{MW} \times 10^{6}$ & $\mathrm{MW} \times 10^{6}$ & $\begin{array}{l}\text { Sedimentation } \\
\text { coefficient }\end{array}$ & $\mathrm{MW} \times 10^{6}$ \\
\hline PCRMV & $3.32 \pm 0.12^{\mathrm{b})}$ & $3.49 \pm 0.08^{\mathrm{b})}$ & $39.6 \pm 1.5^{\mathrm{c})}$ & 3.16 \\
PnMV-PN & $3.34 \pm 0.08$ & $3.48 \pm 0.16$ & $36.9 \pm 0.1$ & 2.73 \\
PnMV-T & $3.38 \pm 0.11$ & $3.72 \pm 0.09$ & $37.5 \pm 0.8$ & 2.82 \\
BICMV & $3.35 \pm 0.19$ & $3.63 \pm 0.13$ & $38.3 \pm 0.8$ & 2.95 \\
BCMV & $3.33 \pm 0.17$ & $3.63 \pm 0.10$ & $39.7 \pm 1.5$ & 3.18 \\
SMV & $3.37 \pm 0.07$ & $3.57 \pm 0.10$ & $37.1 \pm 0.9$ & 2.76 \\
TuMV & $3.06 \pm 0.12$ & $3.44 \pm 0.12$ & $39.3 \pm 1.4$ & 3.13 \\
\hline
\end{tabular}

a) Denaturation was carried out in $10 \mathrm{mM} \mathrm{Na-P.B.,} \mathrm{pH} 7.0$ containing $1 \mathrm{M}$ glyoxal and $50 \%(\mathrm{v} / \mathrm{v})$ dimethyl sulfoxide.

$b, c)$ The values of $b$ and $c$ are means of 6-13 and 5-14 determinations, respectively.

terminations. It is generally assumed that the smaller components are associated with the degradation of the coat protein subunits during purification and storage.

The authors thank Dr. H. Tochihara, Mr. Y. Minobe and Dr. K. Hanada for their suggestions.

\section{和 文 摘 要}

福本文良・岩木满朗·土㥓常男 : Peanut chlorotic ring mottle virus の RNA と外被蛋白の諸性犋

Potyvirus group に属する peanut chlorotic ring mottle virus (PCRMV) の純化標品から分離した核酸 は, DNase に耐性であるが, RNaseに対して感受性であり,ウイルス活性が消失した。また，ホルムアルデ ヒド処理核酸は, 紫外線吸収曲線の吸収極大の位置が長波長に動き, 吸収も増大することから, PCRMV 核酸

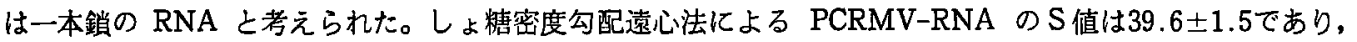
この值から分子量は $3.16 \times 10^{6}$ と計算された。アガロースゲル電気泳動法に上る末変性 RNA の分子量は 3.32 $\pm 0.12 \times 10^{6}$ であり, Glyoxal 処理によって変性した場合 $3.49 \pm 0.08 \times 10^{6}$ が得ら机た。一方, 外被蛋白の分 子量はポリアクリルアミドゲル電気泳動法によって35,600であった。 